\title{
Dracula Tourism as Pilgrimage?
}

\section{Pilgrimage and tourism}

Several studies have been made of the connections between pilgrimage and tourism. The sentence 'a tourist is half a pilgrim, if a pilgrim is half a tourist' by Victor and Edith Turner is one of the most quoted lines on the subject (Turner \& Turner 1978: 20). Erik Cohen has stated, quoting Gilbert Dupont, that in modern mass-pilgrimage the actual behaviour of pilgrims is often indistinguishable from that of tourists (Cohen 1992a: 53). Juan Eduardo Campo argues that in the late twentieth century pilgrimage and tourism are seldom easily distinguishable and pilgrimage often invites tourism, while tourism entertains the possibility of pilgrimage experiences (Campo 1998: 53).

Tourism and pilgrimage have many things in common, especially in the modern age. Although pilgrimage is motivated by a religious basis, it still has characteristics which are not motivated by religion. The secular aspects of pilgrimage, such as, for example, the problem of finding accommodation, organizing the trip especially for a large number of people, the problem of food, eating and healthcare are the same as in modern mass tourism (Vukonić 1996: 137-8). Culture and heritage have become important elements in tourism. The World Tourism Organization estimates that they are a component in almost 40 per cent of all international trips undertaken. Because many pilgrim sites have also become secular heritage tourism sites, pilgrimage, religious tourism and tourism have also come closer to one another (Timothy \& Boyd 2003: 1, 28-33).

Sightseeing can be viewed as a modern ritual and the tourist as a contemporary pilgrim who searches for authenticity in other times and places than his or her everyday life (MacCannell 1999: 13; Urry 2002: 9). Authenticity is a shared ideal between tourism and pilgrimage. A pilgrimage site should at least in some way be authentic to the pilgrim whether it is historically authentic or sanctioned as authentic by a religious authority (Schott 2006: 316). A pilgrim site has to be, or at least it has to feel, authentic in order for the pilgrim to really experience it. Although the need for authenticity in tourism is questioned and challenged by many scholars, it is nevertheless still an 
important part of tourism. ${ }^{1}$ However, the question of authenticity in tourism is not an easy one. In order to fully understand the role of authenticity in tourism we have to split the concept of authenticity into two: firstly the historical and scientifically measured authenticity and secondly the felt or experienced authenticity (Hovi 2008b: 85). Sometimes the tourist may have an authentic experience even though the surroundings might not be authentic in the strict sense of the term. In my opinion the feeling and the experience of authenticity is common both in tourism and in pilgrimage, whether the actual site is historically authentic or not.

According to Alan Morinis, pilgrimage 'is a journey undertaken by a person in quest of a place or state that he or she believes to embody a valued ideal' (Morinis 1992: 4). Pilgrimage can therefore be seen as existing beyond the original religious realm and having a meaning which allows secular journeys to be included. Pilgrimage can for example include travel to sites that symbolize nationalistic values and ideals, disaster sites, places related to the lives of literary writers and the settings of their novels, places associated with musicians and other known figures from popular culture, as well as places associated with historical persons and events (Olsen \& Timothy 2006: 5). In his article about American domestic pilgrimages, Juan Eduardo Campo divides American pilgrimage into three categories: 1) pilgrimages connected to organized religion, 2) pilgrimage connected with American civil religion and 3) pilgrimage connected with cultural or implicit religion. According to Campo the third group comprises pilgrimages that incorporate elements from cultural values and practices but which are distinct from organized religions and civil religion. As an example Campo mentions Disneyland or Disney World and Graceland, the family mansion of Elvis Presley (Campo 1998: 44, 51).

Even though pilgrimage and tourism have a lot in common, not every tourist is a pilgrim and not every pilgrim is a tourist. However, it can sometimes be hard to find the distinction between pilgrims and tourists. There are places where pilgrimages have undergone a touristic metamorphosis and where the behaviour of quasi-believers cannot be characterized as very religious (Vukonić 1996: 138). At some pilgrimage sites the behaviour of some of the pilgrims is seen as less real then the behaviour of others. In their purchases, many pilgrims behave like tourists. For example in the famous pilgrimage site of Lourdes some of the pilgrims criticize other pilgrims who have bought mementos. The pilgrims who criticize others may also have implied

1 For the discussion about authenticity in tourism see, for example, Urry 2002, and Timothy \& Boyd 2003. 
that the purchasers, at least in this respect, are not real pilgrims because they are behaving just like normal tourists (Eade 1992: 28). Erik Cohen has made a distinction between tourists and pilgrims in terms of the direction of their journeys. Cohen uses Victor Turner's concept of the pilgrimage centre. The pilgrim journeys toward the socio-cultural centre of his or her society, while the tourist journeys away from it towards the periphery. Pilgrims are travelling toward the place or centre they believe to be sacred and where they can share the place with people who believe as they do. Tourists on the other hand are travelling toward the other and towards something different. Instead of the centre they are travelling to the margins (Schott 2006: 303). This distinction is not so clear when the centre is located in the socio-cultural and geographical periphery of the pilgrim's society and the pilgrimage will take up aspects of tourism. In these cases Cohen makes the distinction between a pilgrim-tourist and a traveller-tourist in terms of whether or not the destination is a pilgrimage centre of his or her own religion or socio-culture (Cohen 1992b: 49).

This article is about Dracula tourism in Romania and how it may be seen as pilgrimage. I will approach this connection especially through the place myth of Transylvania and through the status Transylvania has in Western popular culture. In this article I will approach the subject purely from a 'Western' point of view. By this I mean that in this article Romania, although a member of the EU and NATO, is treated not as part of the West but part of the East. This is due to the fact that in Western popular culture Romania and especially Transylvania have always been portrayed as the Other in relation to the West. Because the Western popular culture plays a significant role in Dracula tourism, I consider this point of view to be justified.

\section{Dracula tourism}

Dracula tourism is tourism which is centred on either the fictional vampire Count Dracula, or the historical Dracula, a fifteenth-century Wallachian (i.e. an inhabitant of the southern part of modern day Romania) ruler called Vlad the Impaler. In Dracula tourism these two characters are often conflated, or sometimes even melded together, into one Dracula figure. This linkage between the historical and the fictional Dracula is and has been the basis of Dracula tourism in Romania, even though the linkage is vague at best and often also very artificial. The fictional vampire Count Dracula first appeared as the main character in Bram Stoker's book Dracula in 1879. Since then the 
character has appeared in numerous books, movies, games, theatre plays and TV-shows. The historical Dracula, Vlad the Impaler, was a Wallachian ruler, a voivode who lived in the fifteenth century and was also known as Vlad Dracula. Vlad became famous in printed German and Russian stories as well as in the Romanian oral tradition about him, which were circulated around Western Europe and Russia in the fifteenth and sixteenth centuries. Many of these stories portrayed Vlad as a cruel madman and as a bloodthirsty tyrant. This was the case especially in the German versions. (Boia 2001: 226-9).

Because of Vlad the Impaler's infamy, it has been easy to connect him to the monstrous vampire of fiction. Especially a work of two American scholars, Radu Florescu and Raymond T. McNally, has promoted this connection. According to Elizabeth Miller, their book In Search of Dracula is still considered to be one of the primary texts of Dracula studies in spite of its flaws. It was not the first to suggest the connection between Vlad the Impaler and the vampire count, but it is considered to have brought the connection to a larger audience (Miller 2000: 180-1). In reality, however, apart from a few obscure references to historical events in Stoker's book, the only thing that Vlad the Impaler, or Vlad Dracula, and the vampire Count Dracula have in common is the name Dracula (Miller 2000: 188-9). Despite the artificiality of the connection, vampire Dracula and Vlad the Impaler have become synonymous in the media and in popular culture, and partly also in the tourism industry. In my opinion this is due to the position Dracula enjoys in Western popular culture. This is evident in Dracula tourism, where the name Dracula is often used of both Vlad the Impaler and the fictional vampire count. Because the connotations between the name Dracula and vampires are so strong, tourists may automatically think of the vampire even when actually hearing about Vlad the Impaler (Hovi 2008a: 83).

An essential part of Dracula tourism consists of the Dracula tours. These tours visit locations somehow linked to either one of the Draculas. Dracula tours can be divided roughly into three different types: 1) tours that concentrate on the life of Vlad the Impaler and the historical sites connected with him, 2) tours that concentrate on the fictional vampire Count Dracula and locations connected with Bram Stoker's book, and 3) tours that mix both the fictional Dracula and Vlad the Impaler. Sites connected to Vlad the Impaler include, for example, the assumed birth and burial places of Vlad; the city of Sighişoara and the monastery at Snagov. Other sites include the cities Bucharest and Târgovişte where Vlad lived and ruled, and the two castles connected with him, Bran and Poienari. The sites connected strictly to Bram Stoker's book include only two places, the city of Bistrița and the Hotel Castle 


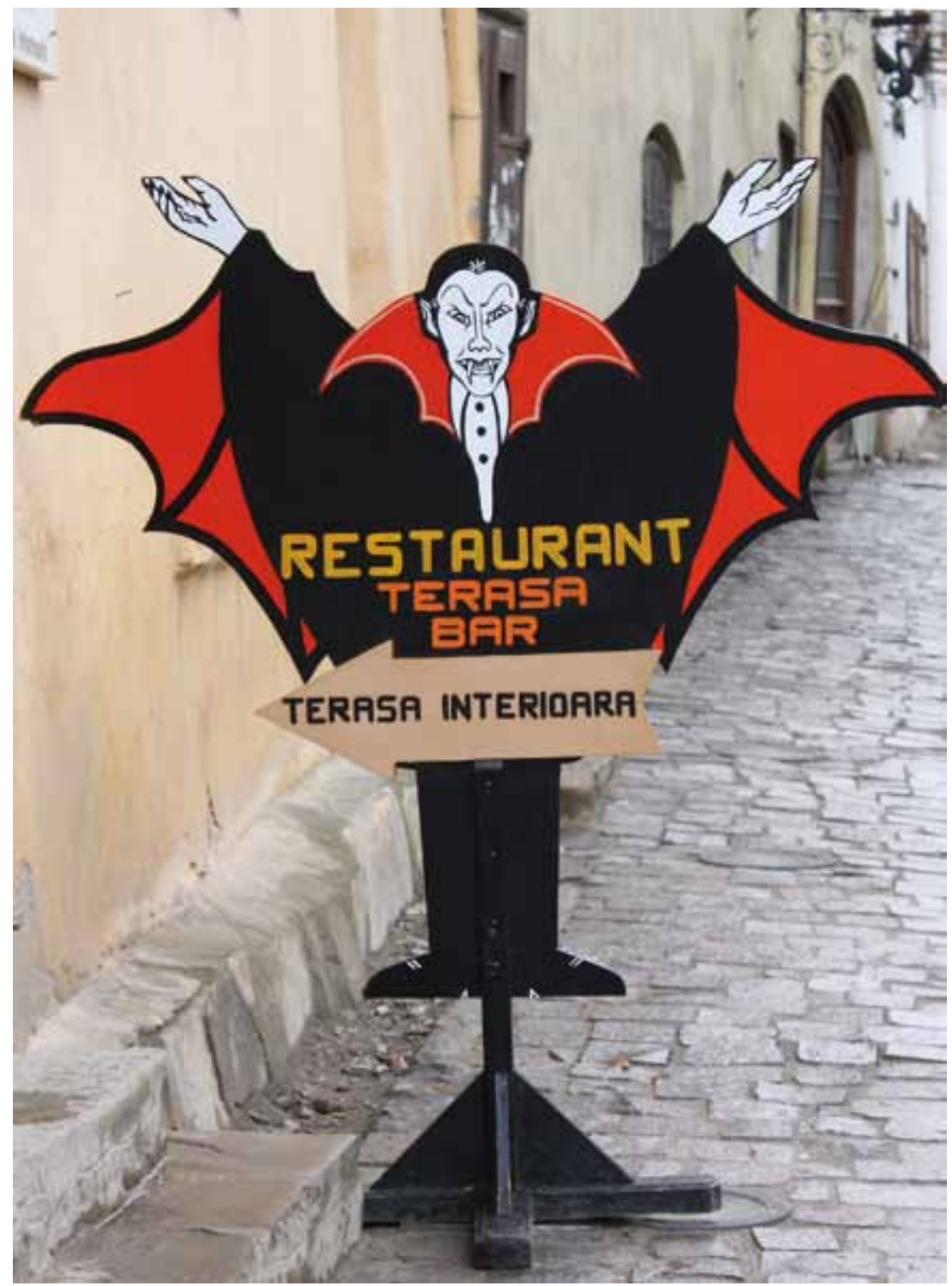

Sighişoara. A figure of the vampire Dracula outside the house where Vlad the Impaler is thought to have been born. Today the house is a restaurant called 'Casa Vlad Dracul'. Photo $\odot$ Tuomas Hovi 2010. 


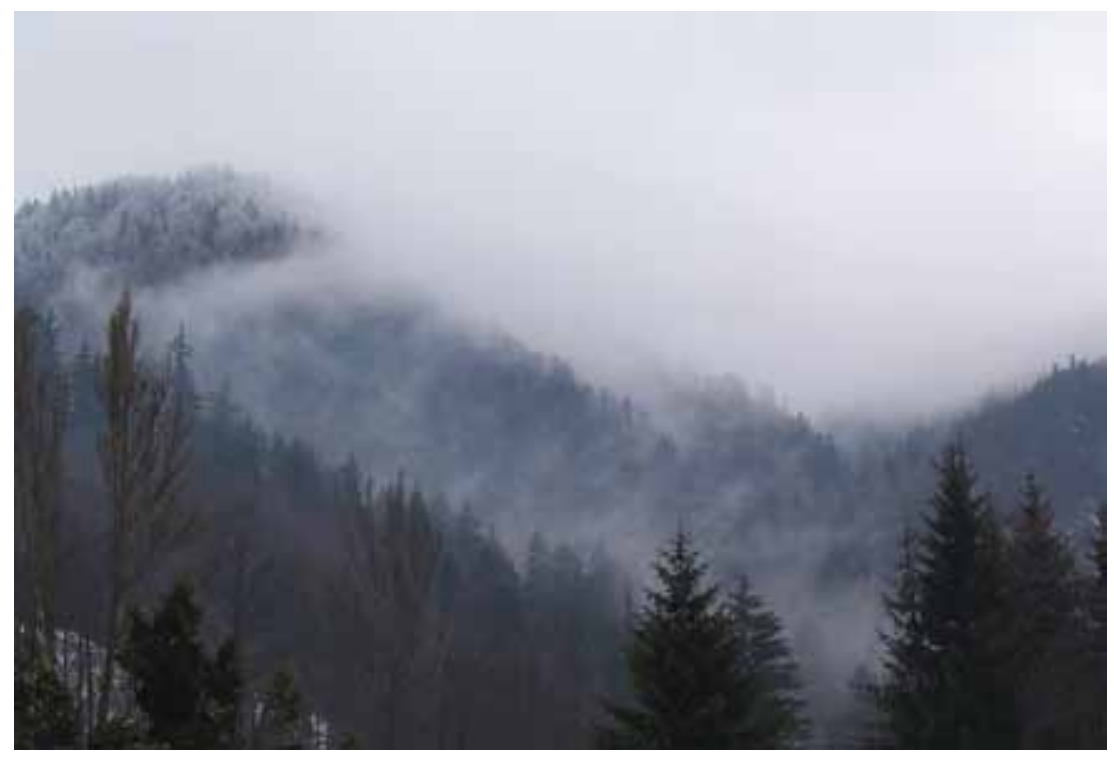

Transylvania. The Carpathian Mountains near the border to Wallachia. Photo $\odot$ Tuomas Hovi 2010.

Dracula which is built in the general location of Dracula's castle in Bram Stoker's novel. In addition to these two, the whole region of Transylvania can in a way also be seen as a 'Dracula site' (Hovi 2008a: 73-4).

\section{The place myth of Transylvania and Dracula tourism}

When Bram Stoker published his novel he sealed the place myth of Transylvania. A place myth is a set of place-images which hold various discrete meanings associated with real places or regions, regardless of their character in reality. These place-images result from stereotyping and they may be accurate or inaccurate (Shields 1991: 60-1). Towards the end of the nineteenth century Transylvania had already been described as a supernatural and a backward part of Europe by writers like Emily Gerard and Jules Verne, but it was Bram Stoker's Dracula that made the most significant contribution to the place myth of Transylvania (Light 2008: 8). Because of the success of Dracula and its influence on popular culture ever since, Transylvania has become known as a land of superstition, vampires and myths, an 'in-between' place that holds a unique position in Western popular culture. In the Western popular imagin- 
ation Transylvania has become synonymous with the supernatural. In a way Transylvania is an anomaly-it is a part of modern and rational Europe, and at the same time it is not. Transylvania can also be seen as a liminal space; it is somewhere between the known and the unknown worlds, between the past and the present and between the sacred and the profane realms. The journey to Transylvania can be seen as a metaphorical crossing of an imagined spatial or temporal threshold (Light 2009: 188; Pritchard \& Morgan 2006: 764). This image of Transylvania is so strong that many Westerners think that it exists only in the minds of fiction writers and film-makers and express surprise when they learn that Transylvania actually exists as a real region (Hupchick 1995: 49). In the Western imagination Transylvania, as well as the whole of Romania, has become the home of the vampire Count Dracula, Dracula's country.

In addition to popular culture, the tourism industry also uses and upholds the place myth of Transylvania. Many travel agencies use the 'Transylvania discourse' in their advertising and tour itineraries. By 'Transylvania discourse' I mean the images and stereotypes that are being used in describing Transylvania as a magical, mystical, mysterious and terrifying place (Hovi 2008a: 76-7). The 'Transylvania discourse' is used differently by different travel agencies. In some cases the 'Transylvania discourse' is only hinted at and in some cases it is blatantly obvious. For example, in a tour itinerary from a travel agency called 'Company of Mysterious Journeys' it is stated that the traveller can spend the first day safe because he or she is still in Wallachia. It is only on the second day that the tour reaches Transylvania. ${ }^{2}$ On the other hand a tour itinerary by a travel agency called 'Beyond the Forest' states that the traveller should remember that Transylvania is 'a land of myths, superstitions and the omnipresent feeling of danger.' ${ }^{3}$ Although Dracula tours are offered through out the year, the season of Halloween is the most fascinating. Most of the travel agencies that organize Dracula tours have special Halloweenthemed Dracula tours. These tours also visit locations connected to both the historical and the fictional Dracula, but the emphasis is on vampires and the horror aspect of Bram Stoker's Dracula. Many Dracula tours and especially the Halloween tours include some sort of performance at some point of the tour. In some performances the tourists are only observers as, for example,

2 Company of Mysterious Journeys. Weekend with Dracula [online]. http://www. mysteriousjourneys.com/dracula_tours/long_weekend_dracula/ (accessed on 26 June 2009).

3 Beyond the Forest. Ultimate Halloween [online]. http://www.beyondtheforest.com/ Romania/DRACUH.html (accessed on 26 June 2009). 
in watching a witch trial or a vampire hunt. In some performances the tourists are also participants as, for example, in a Halloween costume party. ${ }^{4}$ The elements of fantasy, escapism and play are important parts of Dracula tours and especially of the Halloween tours.

Dracula tourism, especially through the place myth of Transylvania, offers the traveller a chance to experience something that is seen as being lost in the secular modern West. The place myth has depicted Transylvania, and maybe the whole of Romania, as the complete opposite of the so-called civilized and rational Western world, in other words it is viewed as the Other in relation to the Western world. The images of Transylvania in Stoker's book and in nineteenth-century Western Europe were the projections of Western fears onto the East (Andras 1999: 2, 8). In Stoker's book and in Western European nineteenth-century literature, Transylvania was depicted in much the same way as today, but the attitude towards it seems to have changed. In Stoker's book modernization, rationality and technology are seen as admirable and the lack of it as negative. The modern image of Transylvania and the attitude towards it seems to be quite the opposite. Transylvania is seen as a mysterious and interesting place where Western progress and rationality have not yet been able to influence or even corrupt it. Modernization, rationalization and technology are seen as something negative. Although Transylvania is still also connected with vampires, evil and horror, it is regarded as fascinating rather than forbidding. This is part of a larger trend in tourism that is especially clear in the Middle Ages tourism boom. According to Lotten Gustafsson, the Middle Ages and medieval man have become the symbolic carriers of everything that has been lost or rejected in modern times (Gustafsson 2002: 269). The Dracula tourist can be seen as taking the trip to experience something deeper and special, something that has been lost or rejected in his or her everyday life surroundings.

\section{Dracula tourism as pilgrimage}

Referring to the earlier definition of pilgrimage by Alan Morinis as a journey to a place that the person believes to embody a valued ideal, I would suggest that Transylvania is such a place (Morinis 1992: 4). As stated above, Transylvania 
holds a special place in Western popular culture. Through the place myth of Transylvania many Westerners share the idea of Transylvania as both a mysterious, magical and supernatural place, as well as a land untouched by modern Western progress. This idea of a mysterious, time-forgotten place is a shared and valued ideal, especially for those under the influence of Western popular culture. Through the place myth, Transylvania has become a place of shared ideals that attracts many tourists. There are, however, many different motivations behind Dracula tourists' participation. Some tourists seek the literary roots of Bram Stoker's Dracula, some the supernatural roots of Dracula and the vampire phenomenon, and some tourists take part in Dracula tours just for fun and general interest. Duncan Light interviewed a group of twentyone tourists who took part in a Dracula tour during the Halloween of 2004. Most of the interviewed tourists had a preconceived image of Transylvania as a place which is something special or something extraordinary. To them Transylvania was a place that embodied a valued ideal of being special and more than the mundane existence in the modern Western world. One participant stated that she did not actually believe in the supernatural, but could still get enjoyment from it and the pretence that supernatural phenomena exist. There was also a costume party included in the Dracula tour that Light examined (Light 2009: 192-4). The costume party or 'Vampire Ball', which is a part of many Dracula tours, seems to be almost a shared ritual in which the participants dress up and behave according to a shared ideal. It is a 'ritual' wherein one can relax and leave one's inhibitions and restrictions behind, or in fact leave reality behind for an evening, as the participants themselves described the event (Light 2009: 194).

In Dracula tourism Bram Stoker's book obviously plays an important role. Many Dracula tourists go to Romania and Transylvania to find the literary roots of Dracula. These tourists want to visit 'literary places', places associated with writers' biographies, or those which provided the settings for their novels. Literary places are the fusion of reality and fantasy where the boundaries between imagined worlds and real life get blurred. David Herbert has made an analogy between literary tourists and religious pilgrims. He argues that the issue of real and imagined is very relevant in both (Herbert 1995: 33). Literary tourists are actually often called literary pilgrims, people who are prepared to travel long distances in order to experience places linked with writers and their work (Herbert 2007: 102). Pilgrim sites are usually seen as part of a sacred geography. According to James J. Preston, pilgrimage sites are often found in dramatic locations, or places that are located at the crossroads of previous civilizations that have been transformed and synthesized 


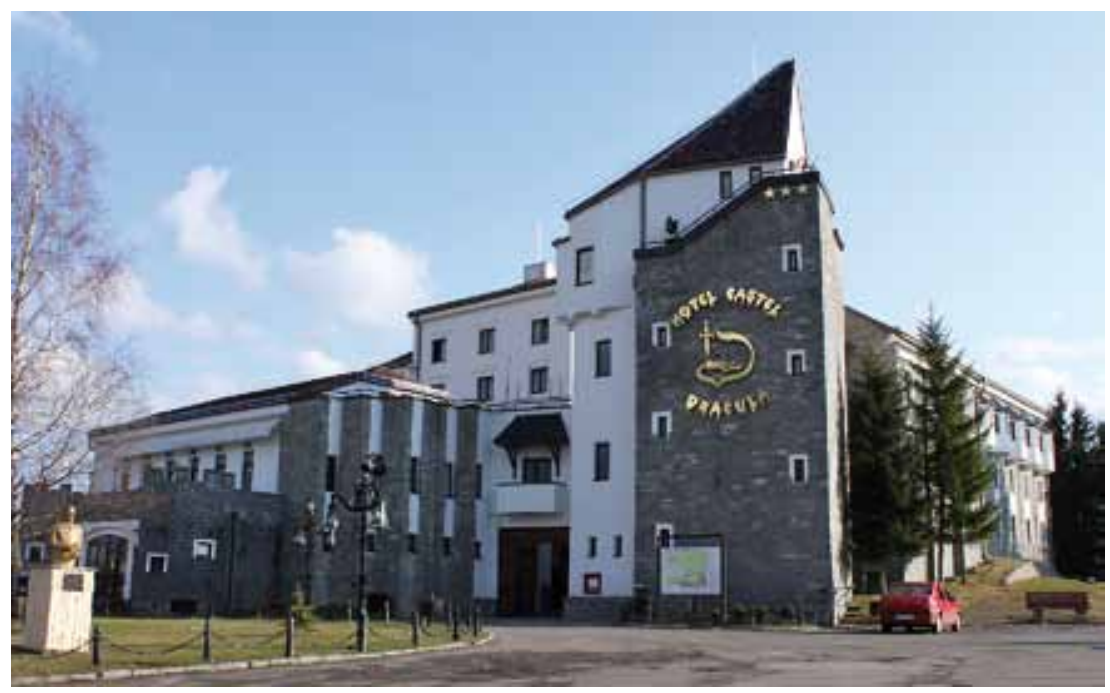

Hotel Castle Dracula build in the general location of the Count Dracula's Castle in Bram Stoker's novel. Photo $\odot$ Tuomas Hovi 2010.

many times by saints or prophets (Preston 1992: 35). Transylvania can also be seen as a part of a sacred geography through the idea of the place myth of Transylvania. This geography is, however, as much a part of imagination as it is real because it is derived from fiction. It is not physical geography but imaginative geography (Light 2008: 14).

Eric Cohen has made a distinction between a tourist and a pilgrim in terms of the socio-cultural meaning of the journey's destination. The pilgrim journeys toward the socio-cultural centre of his or her society, while the tourist journeys away from it and towards the periphery. Dracula tourism is interesting because it can be seen both as moving towards the centre and away from it depending on how the socio-cultural centre is defined. If we define Western popular culture as the socio-cultural centre, then Dracula tourism can be seen as a form of pilgrimage. Then again, Dracula tourism can also be seen as a journey to the periphery, or to the margins of the normal surroundings of the traveller, towards the Other of the socio-cultural centre. In my opinion, in Dracula tourism Transylvania, especially through the place myth of Transylvania, can be seen as being a part of the socio-cultural centre of Western popular culture. This Transylvania is as much a place of imagination as it is real and existing. Dracula tourism as travel to the periphery and to the margins can be explained with historical and socio-political reasons as well 
as through the horror aspect. Romania and Transylvania can be seen as being on the periphery, or representing the Other to the Westerner because of the 50 years of the country's communist regime. During this time Romania was somewhat isolated from the West. Romania, Transylvania, and especially the novel Dracula, have from time to time been connected to the Balkans and to the discourse of Balkanism. Unlike Orientalism, which is a discourse about the opposition between East and West, Balkanism is a discourse about the ambiguity of the whole of south-eastern Europe which is situated at a crossroads between East and West. According to Maria Todorova, the Balkans represent the Other within Europe (Light 2007: 749; Todorova 1997: 15-17, 188).

According to Erik Cohen, although many pilgrim centres can be visited throughout the year, most of them have seasons, during which the pilgrimage is most meritorious (Cohen 1992a: 56). Here we may find another parallel in Dracula tourism. Although Dracula tours are offered throughout the year, Halloween seems to be a special season for Dracula tourism, as noted earlier in this article. Because Halloween itself is associated with horror and the liminality between life and death, it provides a perfect setting, not only of a particular time but also of a state of mind. Halloween can almost be seen as a portal or a gateway from mundane existence to the supernatural, from the profane to the sacred. In her research about the Goddess movement, Kathryn Rountree has stated that a Goddess pilgrim's visit to an ancient pagan temple is not only a journey to a distant place but also an imaginated journey to distant time. The site visited provides a constant link between the past and present worlds (Rountree 2006: 45-6).

Visiting Transylvania, 'the land that time forgot,', the traveller may experience an imagined journey not just to a distant land, but also to a distant time. The aspects of time and history are also interesting in Dracula tourism because of the somewhat anachronistic relationship between the historical and the fictional Dracula. Vlad the Impaler lived and died in the fifteenth century, whereas Bram Stoker's book is set at the end of the nineteenth century. In a way the travellers go through different times as well as different places during the Dracula tours. Many Dracula tours and especially the Halloween Dracula tours start in Bucharest, then show sites connected to Vlad the Impaler in Wallachia and Transylvania before visiting the places associated with Bram Stoker's book, namely Bistrița and the Borgo Pass. While visiting sites assocom/2005\%2oHaunted\%20AttractionDrac\%2oItinerary.htm (accessed on 1 July 2009). 


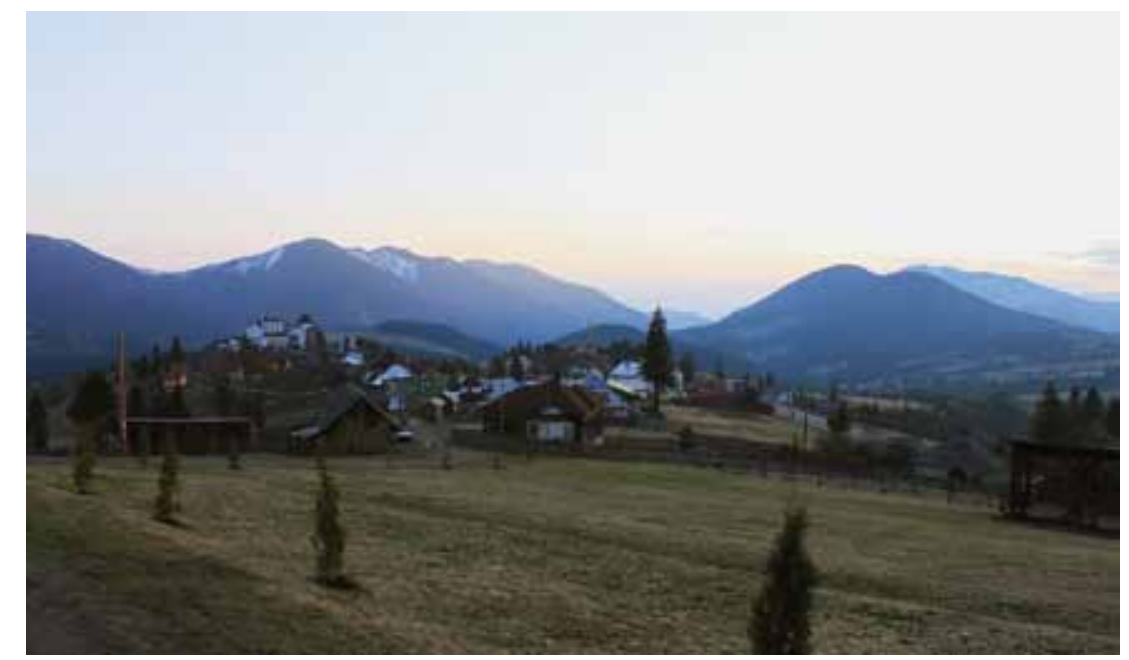

Hotel Castle Dracula in the Borgo Pass. Photo @ Tuomas Hovi 2010.

ciated with Vlad the Impaler, the tour guides usually tell stories about Vlad that relate to those sites. For example, in the ruins of the Poienari fortress, tour operators tell how Vlad's wife threw herself into the river below while the enemy was approaching, or how the treacherous landlords were forced to build the fortress. ${ }^{6}$ Other similar sites include, for example, Sighişoara where Vlad is believed to have been born and Târgovişte where Vlad lived and ruled. In Sighişoara one can 'Stroll around the streets of the old citadel, just like Vlad Dracula did once, hundreds of years ago' or have dinner in 'the very place where Dracula was born.7 By visiting such sites the tourist can get closer to the historical Dracula and even relive the events. Similarly, by visiting the sites believed to be scenes of the life of a religious founder, the pilgrim relives those events in imagination (Turner \& Turner 1978: 33). Here we find the common thread of authenticity. To visit the same authentic place where the religious founder, or in the case of Dracula tourism, Vlad the Impaler has been, enhances the experience of authenticity.

6 See, for example, Quest Tours \& Adventures. Dracula: Myth and History [online]. http://www.romtour.com/DRACULA-MYTH-AND-HISTORY.htm (accessed on 9 July 2009).

7 Travel Library. Dracula Tour Vampire In Transylvania [online]. http://www.travellibrary.com/tours/europe/romania/brasov/dracula_tour_vampire_in_transylvania. html (accessed on 9 July 2009). 
The sites associated with Bram Stoker's book seem to be the highlight or the turning point of the Dracula tour. After these sites the tour usually continues for a few more days visiting historical and cultural sites before the end of the tour and the departure back home. The itinerary of the pilgrim is not only a simple geographical route, but also a symbolic ascent from the profane daily existence to the sacred. In a similar way we may say that the Dracula tourist follows a symbolic itinerary from the profane to the sacred as he or she travels from the historical Wallachia and Transylvania to the mystical and supernatural Transylvania, from the profane to the sacred, or at least from the profane to the supernatural.

\section{Conclusion}

Dracula tourism and pilgrimage share some common features. Both pilgrimage and Dracula tourism have seasons in which the journey is more meaningful and they both share a sacred geography or sacred places. The most important aspect of Dracula tourism when linking it to pilgrimage is the place myth of Transylvania. Transylvania has become something much more than just a

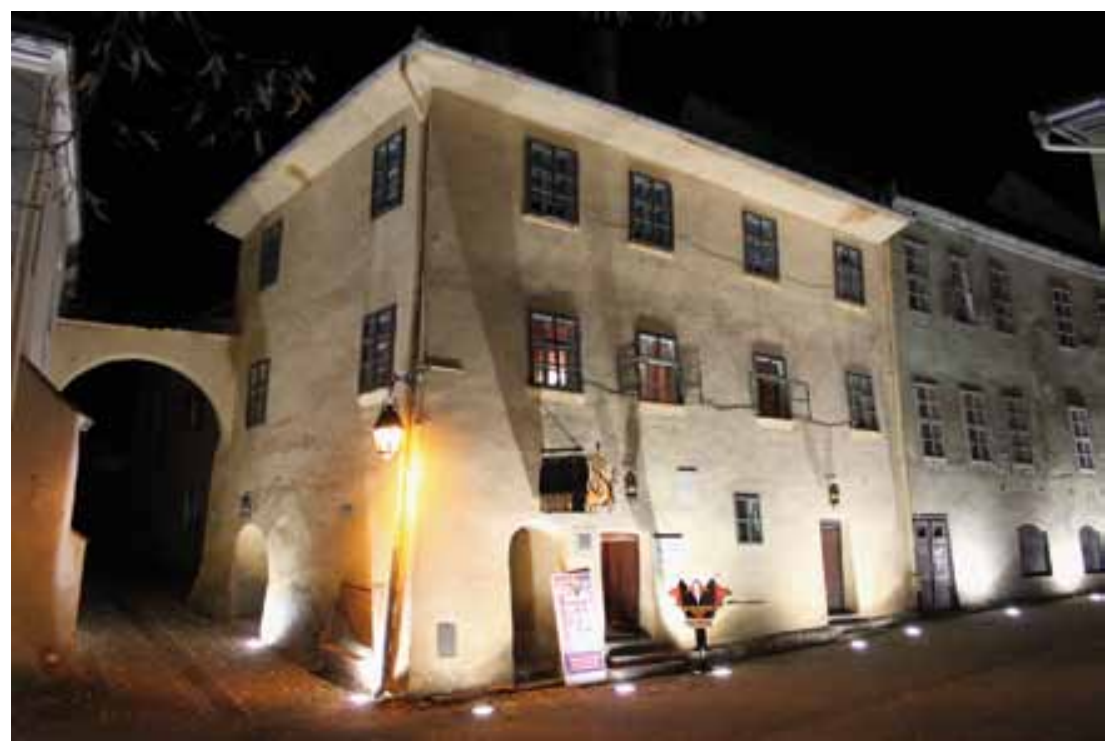

The house in Sighişoara where Vlad the Impaler is thought to have been born. Photo (c) Tuomas Hovi 2010. 
historical province that has been a part of Romania since 1918. Transylvania has become a mystical and a mythical land, almost a utopia. At the same time it is also a 'normal' part of a modern country where people live their everyday lives. The place myth of Transylvania provides a common and shared valued idea of a mystical and almost a sacred place untouched by modernity. This idealistic and romanticized vision combined with the idea of vampires, horror and the supernatural makes Transylvania a pilgrimage site for those who seek it. In Dracula tourism the boundaries between imagination, reality and experience are blurred. The experience of the tourist can be compared to the experience of a pilgrim. By seeking the historical, literary or the supernatural roots of Dracula, the tourist can be viewed as seeking some kind of a higher or deeper experience than just a 'normal' tourist experience would be. Although Dracula tourism can be examined in terms of pilgrimage, not all of the tourists can, or even should be, seen as pilgrims. Pilgrimage nevertheless offers a new and interesting point of view in researching Dracula tourism.

When thinking about Dracula tourism as pilgrimage the emphasis is on the fictional Dracula and the places attached to him and not on the historical Dracula, Vlad the Impaler. Although interest in Vlad the Impaler and the historicity of his life is growing, the fictitious vampire is still the main attraction in Dracula tourism. The connection to fiction is even greater when the two characters are combined into one character. In these cases the historical Dracula Vlad the Impaler is linked to a supernatural being, the vampire Dracula. This in a way gives legitimacy to the fictitious figure.

Although we may argue that tourism and pilgrimage have become almost indistinguishable, there are still differences between them. We may argue that there are pilgrims who act more like tourists than actual traditional pilgrims. At the same time, not every tourist can be viewed as a pilgrim. In my opinion it all depends on the person who is taking the trip, whether he or she is a pilgrim searching for something deeper and meaningful or is just looking for a good time. Whether or not the traveller thinks of herself or himself as a pilgrim and whether it is possible for an outsider to label the traveller as a pilgrim depends, in my opinion, on two things; first, on the reasons for the travel and second, on the preconceived ideas that the traveller might have about the destination. So a Dracula tourist can be a Dracula pilgrim searching for the supernatural in mystical Transylvania, or, a Dracula tourist can be just that-a Dracula tourist. 


\section{References}

Bibliography

Andras, Carmen Maria

1999 The Image of Transylvania in English Literature. Journal of Dracula Studies 1. http://www.blooferland.com/drc/index.php?title=Journal_of_Dracula_ Studies\#Number_1_.281999.29.

\section{Boia, Lucian}

2001 Romania. London: Reaktion Books Ltd.

\section{Campo, Juan Eduardo}

1998 American Pilgrimage Landscapes. Annals of the American Academy of Political and Social Sciences 558: 40-56.

\section{Cohen, Erik}

1992a Pilgrimage and Tourism: Converge and Divergence. In: Alan Morinis (ed.), Sacred Journeys. The Anthropology of Pilgrimage; pp. 47-61. Westport, CT: Greenwood Press.

1992b Pilgrimage Centers. Concentric and Excentric. Annals of Tourism Research 19: $33-50$.

\section{Eade, John}

1992 Pilgrimage and Tourism in Lourdes, France. Annals of Tourism Research 19: 18-32.

\section{Gustafsson, Lotten}

2002 Den förtrollade zonen. Lekar med tid, rum och identitet under medeltidsveckan på Gotland. Nora: Bokförlaget Nya Doxa.

\section{Herbert, David T.}

1995 Heritage as Literary Place. In: David T. Herbert (ed.), Heritage, Tourism and Society; pp. 32-48. London: Mansell.

2007 Literary Places, Tourism and the Heritage Experience. In: Dallen J. Timothy (ed.), The Heritage Tourist Experience. Critical Essays. Vol. 2; pp.101-22. Aldershot: Ashgate.

\section{Hovi, Tuomas}

2008a Dracula tourism and Romania. In: Silviu Miloiu (ed.), Europe as Viewed from the Margins. An East-Central European Perspective from World War I to Present; pp. 73-84. Targovişte: Valahia University Press.

2008b Tradition and history as building blocks for tourism. In: Silviu Miloiu \& Ion Stanciu (eds), Valahia Journal of Historical Studies 10; pp. 75-85. Targovişte: sc Editura Logos srl.

\section{Hupchick, Dennis P.}

1995 Conflict and Chaos in Eastern Europe. Basingstoke: Macmillan.

\section{Light, Duncan}

2007 Dracula tourism in Romania. Cultural Identity and the State. Annals of Tourism Research 34 (3): 746-65. 
2008 Imaginative Geographies, Dracula and the Transylvania "Place Myth". Human Geographies: Journal of Studies and Research in Human Geography 2: 5-16.

2009 Halloween in Transylvania. In: M. Foley \& H. O’Donnell (eds), Trick or Treat: Halloween in a Globalising World; pp. 186-200. Newcastle: Cambridge Scholars Publishing.

\section{MacCannell, Dean}

1999 The Tourist: a new theory of the leisure class. Berkeley: University of California Press.

\section{Miller, Elizabeth}

2000 Dracula. Sense \& Nonsense. Essex: Desert Island Books Ltd.

\section{Morinis, Alan}

1992 Introduction: the Territory of the Anthropology of Pilgrimage. In: Alan Morinis (ed.), Sacred Journeys. The Anthropology of Pilgrimage; pp. 1-28. Westport, CT: Greenwood Press.

\section{Olsen, Daniel H. \& Dallen J. Timothy}

2006 Tourism, Religion and Spiritual Journeys. Abingdon: Routledge.

\section{Preston, James J.}

1992 Methodological Issues. In: Alan Morinis (ed.), Sacred Journeys. The Anthropology of Pilgrimage; pp. 31-46. Westport, CT: Greenwood Press.

Pritchard, Annette \& Nigel Morgan

2006 Hotel Babylon? Exploring hotels as liminal sites of transition and transgression. Tourism Management 27: 762-72.

\section{Rountree, Kathryn}

2006 Journeys to the Goddess: Pilgrimage and Tourism in the New Age. In: Willian H. Swatos (ed.), On the Road to Being There: Studies in Pilgrimage and Tourism in Late Modernity; pp. 33-6o. Boston: Brill Academic Publishers.

\section{Schott, Sarah Bill}

2006 Pilgrims, Seekers and History Buffs: Identity Creation Through Religious Tourism. In: William H. Swatos (ed.), On the Road to Being There: Studies in Pilgrimage and Tourism in Late Modernity; pp. 297-327. Boston: Brill Academic Publishers.

\section{Shields, Rob}

1991 Places on the Margin. Alternative geographies of modernity. London: Routledge.

\section{Timothy, Dallen J. \& Stephen W. Boyd}

2003 Heritage Tourism. Harlow: Pearson Education.

\section{Todorova, Maria}

1997 Imagining the Balkans. Oxford: Oxford University Press.

Turner, Victor \& Edith Turner

1978 Image and pilgrimage in Christian culture. New York: Columbia University Press. 


\section{Urry, John}

2002 The Tourist Gaze. London: SAGE Publications.

Vukonić, Boris

1996 Tourism and Religion. Oxford: Pergamon.

Internet sites

\section{Beyond the Forest}

'Ultimate Halloween'. http://www.beyondtheforest.com/Romania/DRACUH.html (accessed on 26 June 2009).

\section{Company of Mysterious Journeys}

'Weekend with Dracula'. http://www.mysteriousjourneys.com/dracula_tours/long_ weekend_dracula/ (aceessed on 26 June 2009).

\section{Quest Tours \& Adventures}

Dracula: Myth and History. http://www.romtour.com/DRACULA-MYTH-ANDHISTORY.htm (accessed on 9 July 2009).

\section{Tours and Events}

Summer Dracula Tour. http://www.toursandevents.com/2005\%20Haunted\%20 AttractionDrac\%2oItinerary.htm (accessed on 1 July 2009).

\section{Transylvania Live}

'Halloween in Transylvania with Vlad the Impaler'. http://www.dracula-tour.com/ romania-travel-transylvania/halloween-dracula-tour.html (accessed on 16 July 2008).

\section{Travel Library}

Dracula Tour Vampire In Transylvania. http://www.travel- library.com/tours/europe/romania/brasov/dracula_tour_vampire_in_transylvania.html (9 July 2009). 